\title{
REMOVAL OF AMMONIUM IONS FROM DIGESTED SLUDGE FUGATE BY USING NATURAL ZEOLITE
}

\author{
Aušra MAŽEIKIENĖ, Marina VALENTUKEVIČIENĖ \\ Department of Water Engineering, Vilnius Gediminas Technical University, \\ Saulètekio al. 11, 10223 Vilnius, Lithuania
}

Submitted 02 Nov. 2015; accepted 25 Mar. 2016

\begin{abstract}
Wastewater treatment loadings with total nitrogen can increased by introducing fugate that is saturated with ammonium ions, generated when dewatering wastewater treatment sludge. In this article the possibility to reduce the concentration of ammonium ions in the fugate by the use of natural zeolite (Transcarpatian clinoptilolite) has been analysed. Lab-scale experiments were carried out with different particle sizes zeolite: $0.8-1.6 \mathrm{~mm}, 1.6-2.5 \mathrm{~mm}$ and 2.5-3.2 $\mathrm{mm}$. At the first stage of the experiments, zeolite particles were mixed with fugate and left to settle until a $99 \%$ efficiency of ammonium ion removal was achieved. At the second stage, ammonium ions were removed from the fugate by filtering this liquid through zeolite where the $70-92 \%$ efficiency was achieved. Zeolite saturated with ammonium ions possibly can be used in agriculture as nitrogenous fertilizers. Obtained fertilizer grade of zeolite saturated with fugate can also be produced from the high ammonium nitrogen concentration side-streams separated from wastewater flow from sludge digestion processes.
\end{abstract}

Keywords: sludge fugate, ammonium ion concentration, removal efficiency, zeolite, wastewater treatment.

\section{Introduction}

Urban wastewater treatment is a high priority environmental issue of and a very important task in the area is the reduction of nitrogen and phosphorus loads (Farkas et al. 2005; Cheng et al. 2011). The removal of mentioned pollutants in wastewater treatment units is affected by the composition of the initial wastewater, i.e. the higher the concentrations of nitrogen and phosphorus in the wastewater, the more complicated it is to meet the required threshold values (Fig. 1). The loading of wastewater treatment units with total nitrogen can be increased by using fugate enriched with ammonium, which has been generated when dewatering sludge by means of centrifuges that have been returned to the starting link of the wastewater treatment unit (Constantine 2006; Thornton et al. 2007). The ammonium concentration in the sludge liquor is often between $500-1500 \mathrm{mg} \mathrm{NH}_{4}^{+}$-N/L, e.g. high sludge thickening prior to digestion increases the ammonium concentration Gustavsson 2010).

In this case the ammonium ions that are present in the sludge fugate can increase the concentration of the total amount of nitrogen to be treated by more than $25 \%$ (Thornton et al. 2007). However, the pollution of the influent wastewater with ammonium ions burdens the processes of biological removal of both the nitrogen and phosphorus from the wastewater (Vaboliene et al. 2007). In order to reduce the higher concentration of $\mathrm{NH}_{4}^{+}$, an older activated sludge (approximately 20 days) is needed,

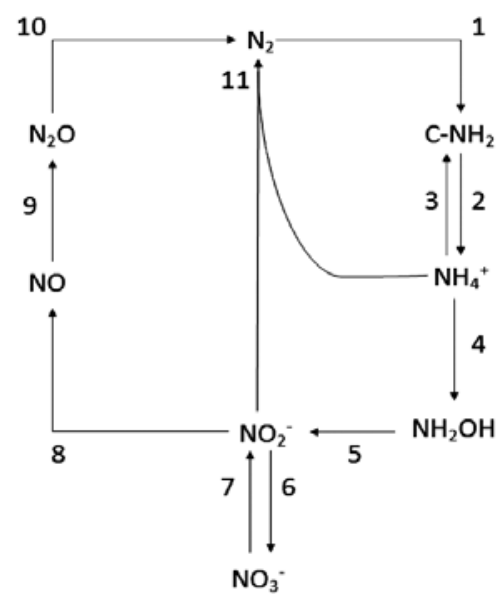

Fig. 1. The main nitrogen compounds transformation processes at WWTP: 1 - gaseous nitrogen fixation, 2 - decomposition of organic material, 3 - assimilation, 4, 5 - nitrification, 6 nitrite oxidation, 7-10 - denitrification (Gustavsson 2010)

Corresponding author: Aušra Mažeikienè

E-mail: ausra.mazeikiene@vgtu.lt 
but this does not provide favourable conditions for the removal of phosphorus. High concentrations of $\mathrm{NH}_{4}^{+}$, in bioreactors and digestion systems inhibit the activity of methanogenic bacteria and prolong the period of digestion (Calli et al. 2005; Tada et al. 2005; Wang et al. 2010).

Vilnius wastewater treatment unit treats $100,000 \mathrm{~m}^{3}$ of wastewater, which equals 660,000 inhabitants equivalent. In addition wastewater treatment sludge is generated, which is thermally treated, digested and dewatered by centrifuges. Technological processes of biological wastewater and sludge treatment are presented in Figure 2.

In scientific literature it is recommended that sludge liquor generated by dewatering the digested sludge should be treated separately before it is returned to the wastewater treatment link (Gustavsson 2010). Sludge liquor can be treated by employing sorption or biological (ANAMMOX) methods. Biological ANAMMOX processes require complex treatments and depend on the period of adaptation as well as on the variability of temperature (Monballiu et al. 2013; Zekker et al. 2014; Bao-Shan Xing et al. 2015), and due to which it is suggested that sorption processes are more appropriate (Vassileva, Voikova 2009; Karapinar 2009).

The aim of the experimental study described in this article, is to analyse the concentration of the fugate saturation with ammonium ions of the dewatered sludge in the Vilnius wastewater treatment plant and to reduce the pollution by either stirring or filtering the sludge liquid through the natural zeolite particles of various sizes. The zeolitic materials are often used in scientific investigations, mostly due to their crystallinity, thermal stability, catalytic, sieve and ion exchange properties, as well as the well-defined cage structure of molecular size (Rožič et al. 2000; Kurama et al. 2002; Du et al. 2005; Miladinovic, Weatherley 2008; Sileg et al. 2010). The most widely used natural zeolite is clinoptilolite (simplified formula $(\mathrm{Na}, \mathrm{K})_{6} \mathrm{Si}_{30} \mathrm{Al}_{6} \mathrm{O}_{72} \cdot 24 \mathrm{H}_{2} \mathrm{O}$ ), whose $\mathrm{K}$ and $\mathrm{Na}$ forms are highly selective for ammonium ions, independent of $\mathrm{NH}_{4}^{+}$concentration (Lebedynets et al. 2004; Inglezakis 2005, Sileg et al. 2010).The advantages of the clinoptilolite are: low cost, high selectivity towards the ammonium ions in the presence of other concurrent cations in the wastewaters and wide spreading in nature (Jafarpour et al. 2010; Ivanova et al. 2010).

The sorption process was chosen because the zeolite that absorbed ammonium ions can be used as fertilizer in agriculture (Rehaková et al. 2004).

\section{Materials and methods}

The samples of sludge liquid after dewatering ( $25 \mathrm{~L}$ of total samples volume) from Vilnius biological wastewater treatment plant were transported to the laboratory of the Water Management Department of Vilnius Gediminas Technical University (Lithuania). The temperature of the liquor samples, $\mathrm{pH}$, and the concentrations of ammonium

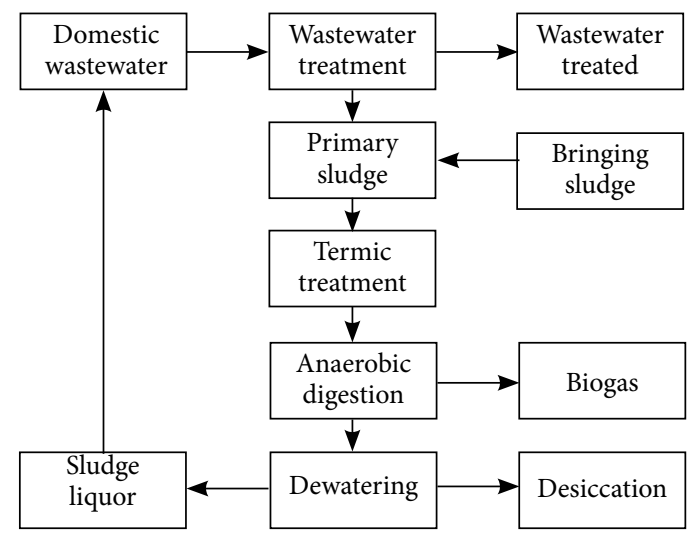

Fig. 2. Conventional technological processes of biological wastewater and sludge treatment

ions and of suspended solids were measured in the laboratory by using of standard approved methods (ISO, EN and LST). The concentration of TSS (total suspended solids) was determined by using a filtering method described in the regulatory document LAND 46-2007 "Water quality. Determination of suspended solids. A filtering method using a fibreglass filter". Vacuum filtering equipment; fibreglass filter with pores of $0.45 \mu \mathrm{m}$; drying unit with a temperature of $105^{\circ} \mathrm{C}$; analytical scales (precision $0.1 \mathrm{mg}$ ) were used. The concentration of total suspended solids was determined 3 times in each sample. To determine the concentration of ammonium nitrogen, "MerckSpectroquant, 1.00683.0001 Ammonium test" test which determination limits are $5.0-150 \mathrm{mg} / \mathrm{L} \mathrm{NH}_{4}{ }^{+}-\mathrm{N}$, and a spectrophotometer "Genesys 10 Vis" (wave length 190-1100 nm) were used. Samples with bigger than $150 \mathrm{mg} / \mathrm{L} \mathrm{NH}_{4}{ }^{+}-\mathrm{N}$ were diluted with distilled water $(1: 10 ; 1: 100$ and $1: 1000$ dilution) and the concentration of ammonium nitrogen was determined accordingly. The studies of $\mathrm{NH}_{4}^{+}{ }^{+} \mathrm{N}$ concentrations in the samples were carried out by using natural zeolite (Table 1), a Transcarpatian clinoptilolite (its mineral content was found to be about $87 \%$ ) of aluminium-silicate origin, which adsorbs high quantities of ammonium (Sakalauskas, Valentukevičienè 2003; Sprinsky et al. 2005; Mažeikienè et al. 2008; Valentukevičienè, Rimeika 2007; Saltah et al. 2007).

The zeolites contain channels, interconnected cavities or voids of a discrete size $(0.4-0.6 \mathrm{~nm})$. The micropores that exist between particles and accompanying materials in the natural zeolites can be occupied by different ions. Previous work in Lithuania observed that this method is an efficient way to achieve ammonium sorption at low cost (Valentukevičienè, Jankauskas 2004). Zeolite fractions (particles of $0.8-1.6 ; 1.6-2.5 ; 2.5-3.2 \mathrm{~mm}$ size) were selected using calibrated sieves. Before the filtration run all zeolite was washed with distilled water in order to remove small particles and dried in an oven at a temperature not exceeding $105^{\circ} \mathrm{C}$. The drying took 2 hours. 
Table 1 . The physico-chemical properties of natural zeolite used in this study

\begin{tabular}{|c|c|c|c|}
\hline \multirow{2}{*}{\multicolumn{2}{|c|}{$\begin{array}{c}\text { Physical properties } \\
\text { Index }\end{array}$}} & \multicolumn{2}{|c|}{ Chemical content } \\
\hline & & Component & $\%$ \\
\hline \multirow{2}{*}{ Porosity } & \multirow{2}{*}{$34 \%$} & $\mathrm{SiO}_{2}$ & 71.5 \\
\hline & & $\mathrm{Al}_{2} \mathrm{O}_{3}$ & 13.1 \\
\hline \multirow{2}{*}{ Density } & \multirow{2}{*}{$2.37 \mathrm{~kg} / \mathrm{dcm}^{3}$} & $\mathrm{Fe}_{2} \mathrm{O}$ & 0.9 \\
\hline & & $\mathrm{FeO}$ & 0.78 \\
\hline \multirow{2}{*}{ Humidity } & \multirow{2}{*}{$4 \%$} & $\mathrm{TiO}_{2}$ & 0.2 \\
\hline & & $\mathrm{MnO}$ & 0.03 \\
\hline \multirow{2}{*}{$\begin{array}{l}\text { Conditional } \\
\text { surface }\end{array}$} & \multirow{2}{*}{$160 \mathrm{~m}^{2} / \mathrm{g}$} & $\mathrm{CaO}$ & 2.1 \\
\hline & & $\mathrm{MgO}$ & 1.07 \\
\hline \multirow{2}{*}{$\begin{array}{l}\text { Mechanical } \\
\text { resistance }\end{array}$} & \multirow{2}{*}{$150 \mathrm{~kg} / \mathrm{cm}^{2}$} & $\mathrm{P}_{2} \mathrm{O}_{5}$ & 0.03 \\
\hline & & $\mathrm{K}_{2} \mathrm{O}$ & 2.85 \\
\hline \multirow[b]{2}{*}{ Attrition } & \multirow[b]{2}{*}{$4 \%$} & $\mathrm{Na}_{2} \mathrm{O}$ & 2.25 \\
\hline & & $\begin{array}{l}\text { Loss on } \\
\text { ignition }\end{array}$ & 5.19 \\
\hline
\end{tabular}

Quality parameters - composition of elements in dry samples of fugate and zeolite (before and after experiments) were analyzed. Each zeolite and fugate sample was homogenized to achieve a uniform appearance, and a mixed sample from each sampling procedure was taken and placed in a ceramics container to access all surface drying. All samples were dried for 11 hours at the temperature of $110^{\circ} \mathrm{C}$ and disintegrated using a porcelain pestle and mortar. Obtained samples were sieved through a 2.0 $\mathrm{mm}$ and $250 \mu \mathrm{m}$ stainless steel sieves, as required for XRay Fluorescence analysis. Sieved samples were analyzed using a Thermo Scientific Niton ${ }^{\circ}$ XL2 X-Ray fluorescence spectrometer. Analytical method of X-ray fluorescence spectrometry and specifically Niton XL2 device for analysis of substances composition was used.

STAGE I. Three 100 and $200 \mathrm{~g}$ samples of three zeolite fractions were mixed with $1 \mathrm{~L}$ of sludge liquor in an automatic mixer for $30 \mathrm{~min}$ at rotation $100 \mathrm{rpm}$ and left to set in for $30 \mathrm{~min}$. All samples were filtered through glass fibre filters with a pore size of $1.0 \mu \mathrm{m}$. The concentration of ammonium ions was measured in the filtered samples.

STAGE II. The experiment to reduce ammonium ion concentrations in the fugate was carried out by filtering it through zeolite filler. The fugate was filtered through constructed columns filters. The columns were $46 \mathrm{~mm}$ in diameter and $1.4 \mathrm{~m}$ high. The filter columns were filled with $0.8-1.6 \mathrm{~mm}$ or $1.6-2.5 \mathrm{~mm}$ zeolite fractions. The hight of zeolite filler was either 0.5 or $1.0 \mathrm{~m}$. The fugate was supplied into the column and filtered at $2 \mathrm{~m} / \mathrm{h}$ filtration rate. After filtered $1 \mathrm{~L}$ of fugate in each case, fugate samples were collected and the concentration of ammonium ions measured. The samples were filtered through glass fibre filters $(47 \mathrm{~mm}$ in diameter) where mesh size was $1.0 \mu \mathrm{m}$. In order to avoid random errors and to obtain more precise results, the concentrations of suspended materials as well as ammonium ions were determined 5 times for each sample.

All results obtained are presented as the arithmetic mean of five replicates. Significant differences $(\mathrm{p}<0.05)$ were removed from the experiment estimations and the measurements were analysed once again. The average concentration was calculated:

$$
\bar{c}=\frac{1}{n} \sum_{i=1}^{k} c_{i} m_{i},
$$

where: $c_{i}$ - concentration of substances at typical points; $m_{i}$ - probability at the occurrence of concentration; $n$ number of trials; $k$ - number of different values of the concentration.

The average concentrations of the variables substances, mentioned above, at the characteristic point were calculated as well. The standard statistical estimation error was evaluated.

\section{Results and discussion}

The characteristics of sludge liquid are described in Table 2.

Table 2. Main characteristics of sludge liquid

\begin{tabular}{ccccccc}
\hline $\begin{array}{c}\text { Sam- } \\
\text { ples }\end{array}$ & $\mathrm{pH}$ & $\begin{array}{c}\mathrm{NH}_{4}^{+} \\
(\mathrm{mg} / \mathrm{L})\end{array}$ & $\begin{array}{c}\mathrm{TSS} \\
(\mathrm{mg} / \mathrm{L})\end{array}$ & $\begin{array}{c}\mathrm{T} \\
\left({ }^{\circ} \mathrm{C}\right)\end{array}$ & $\begin{array}{c}\mathrm{BOD} \\
(\mathrm{mg} / \mathrm{L})\end{array}$ & $\begin{array}{c}\mathrm{COD}_{\mathrm{t}} \\
(\mathrm{mg} / \mathrm{L})\end{array}$ \\
\hline 1 & 7.2 & 1025 & 1040 & 20 & 165 & 2475 \\
2 & 7.4 & 1750 & 1135 & 24 & 176 & 2550 \\
3 & 7.4 & 1720 & 1220 & 23 & 197 & 2498 \\
4 & 7.3 & 1420 & 1093 & 22 & 155 & 2464 \\
5 & 7.4 & 1450 & 1090 & 22 & 205 & 2567 \\
\hline
\end{tabular}

It was determined that the dewatering of digested sludge in the Lithuanian wastewater treatment unit generates a liquid fraction, i.e. fugate, where the ammonium concentration varied from 1025 to $1750 \mathrm{mg} / \mathrm{L}$. The concentration of total COD in fugate was about $2500 \mathrm{mg} / \mathrm{L}$ (BOD$180 \mathrm{mg} / \mathrm{L}$ ) because of degradation of COD and dissolution of ammonium in the digesters (table 2). Clinoptilolite does not affect COD removal, since organic carbon such as COD neither has anionic or cationic charge to adsorb on zeolite, nor could exchange with its cations (Rezaei et al. 2014). The ammonium ions concentrations were approximately two times higher than indicated in the studies done by other researchers (Constantine 2006; Thornton et al. 2007). The $\mathrm{pH}$ values measured for this study were not considerably different and varied between 7.2 and 7.4. In the digesting mechanisms, when anaerobic organic decomposition of organic materials is taking place, the process can be expressed with the formulas below:

$$
\mathrm{C}_{5} \mathrm{H}_{7} \mathrm{O}_{2} \mathrm{~N}+3 \mathrm{H}_{2} \mathrm{O}+\mathrm{H}^{+} \rightarrow 2.5 \mathrm{CO}_{2}+2.5 \mathrm{CH}_{4}+\mathrm{NH}_{4}^{+} \text {. (2) }
$$


The equation shows that the destruction of organic materials leads to an increase of ammonium ions concentration. Sludge liquids contain especially high concentrations of TSS (1040-1220 mg/L). Due to the thermal decomposition of the sludge, which is carried out in the Lithuanian wastewater unit - suspended solids in the fugate are particularly small. Therefore, when sludge is dewatered by using conventional centrifuges the suspended materials cannot be suspended effectively in the dry fraction of the sludge and a high proportion of it obtained into the fugate. TSS concentration is an important characteristic of fugate as it influences either the ion exchange or the sorption process (Hedstrom 2001; Rahmani et al. 2004). Suspended and colloid particles can be attached to the surface of zeolite particles and block the micro pores, thus slowing down the ion exchange.

The results from five laboratory mixers run can be seen in Table 3.

Table 3. Batch test (I) experiment results

\begin{tabular}{ccccc}
\hline No. & $\begin{array}{c}\text { Zeolite } \\
\text { weight, g }\end{array}$ & $\begin{array}{c}\text { Zeolite } \\
\text { particle size, } \\
\mathrm{mm}\end{array}$ & $\begin{array}{c}\text { Removed } \\
\mathrm{NH}_{4}^{+} \text {conc., } \\
\mathrm{mg} / \mathrm{L}\end{array}$ & $\begin{array}{c}\text { Removal } \\
\text { efficien- } \\
\text { cy, \% }\end{array}$ \\
\hline 1 & 100 & $2.5-3.2$ & $40 \pm 4$ & $2 \pm 0.5$ \\
2 & 200 & $2.5-3.2$ & $85 \pm 9$ & $5 \pm 0.4$ \\
3 & 100 & $1.6-2.5$ & $410 \pm 40$ & $24 \pm 2$ \\
4 & 200 & $1.6-2.5$ & $885 \pm 85$ & $51 \pm 5$ \\
5 & 100 & $0.8-1.6$ & $1164 \pm 115$ & $68 \pm 7$ \\
6 & 200 & $0.8-1.6$ & $1540 \pm 150$ & $90 \pm 9$ \\
\hline
\end{tabular}

As can be seen in Table 3, ammonium ions were most efficiently removed by the smallest zeolite fraction when a larger amount of it was used (200 g). Zeolite particle fraction sized 2.5 to $3.2 \mathrm{~mm}$ proved to be inefficient with an efficiency of only $2-5 \%$ of ammonium ions removed from the samples. Therefore, this fraction size was no longer used for further research. Two smaller zeolite fractions sized 0.8 to $1.6 \mathrm{~mm}$ and $1.6-2.5 \mathrm{~mm}$ were used for the reduction of ammonium ions concentration in other fugate samples and Langmuire isotherm was obtained. The following formula was used for the calculations:

$$
q_{e}=\left(C_{0}-C_{e}\right) \cdot \frac{V}{m_{z}},
$$

where: $q_{e}$ - equilibrium adsorption capacity, $\mathrm{mg} / \mathrm{g} ; \mathrm{C}_{0}-$ initial $\mathrm{NH}_{4}^{+}$concentration in the sample, $\mathrm{mg} / \mathrm{L} ; \mathrm{V}$ - volume of the sample, $\mathrm{L} ; m_{z}$ - the adsorbent weight, $g$.

This calculation can be carried out when $q_{e}, C_{0}, C_{e}$ and proportion of $C_{e} / q_{e}$ are known or estimated from the experimental results (Table 4 ).
Table 4. Experimental results of equilibrium adsorption capacity

\begin{tabular}{cccc}
\hline$C_{0}, \mathrm{mg} / \mathrm{L}$ & $C_{e}, \mathrm{mg} / \mathrm{L}$ & $q_{e}$ & $C_{e} / q_{e}$ \\
\hline 1720 & 1310 & 2.05 & 639 \\
1420 & 1210 & 1.05 & 1152 \\
1450 & 1165 & 1.37 & 850 \\
1720 & 835 & 2.21 & 378 \\
1420 & 720 & 1.75 & 411 \\
1450 & 740 & 2.11 & 350 \\
\hline
\end{tabular}

All experimental results were under statistical verification and the following numbers were estimated to plot the adsorption equilibrium presented in Figure 3.

Figure 3 shows the results of the equilibrium adsorption of ammonium ions on zeolite. The experimental data were fitted through the isoterm of Lagmuir, often applied for adsorption equilibrium description for $\mathrm{NH}_{4}^{+}$ removal from water solutions (Vassileva, Voikova 2009; Valentukevičienè, Jankauskas, 2004; Huang et al. 2010). It can be observed that the adsorption equilibrium will be established when $\mathrm{C}_{e} / \mathrm{q}_{e}$ is in the range between 0.6-0.8. A variety of researchers (Huang et al. 2010; Ivanova et al. 2010; Rožič et al. 2000; Vassileva, Voikova, 2009; Sprinsky et al. 2005) describe in their articles the capacity of zeolite to absorb ions from natural water or artificial solutions. The results received in the present study are nearly similar, when compared with such experiments as were carried out with natural zeolite obtained from North-Eastern Rhodope Mountain (Ivanova et al. 2010). An artificial solution made from distilled water and $\mathrm{NH}_{4} \mathrm{Cl}$ was used in the experiments carried out by E. Ivanova and others. Concentration of ammonium ions reached $800 \mathrm{mg} / \mathrm{L}$ and $1 \mathrm{~g}$ of zeolite absorbed up to $9 \mathrm{mg}$ ammonium ions. In the present study $1 \mathrm{~g}$ of zeolite can remove up to $2.2 \mathrm{mg}$ of ammonium ions only (Table 4 ). This is due to high pollution of the sludge liquid (concentration of ammonium ions - up to $1750 \mathrm{mg} / \mathrm{L}$ ) and high TSS concentrations in the fugate (up to $1220 \mathrm{mg} / \mathrm{L}$ ).

At a second stage of the experiments 0.8 to $1.6 \mathrm{~mm}$ sized zeolite particles were tested for the filtration of sludge liquor through zeolite filter media.

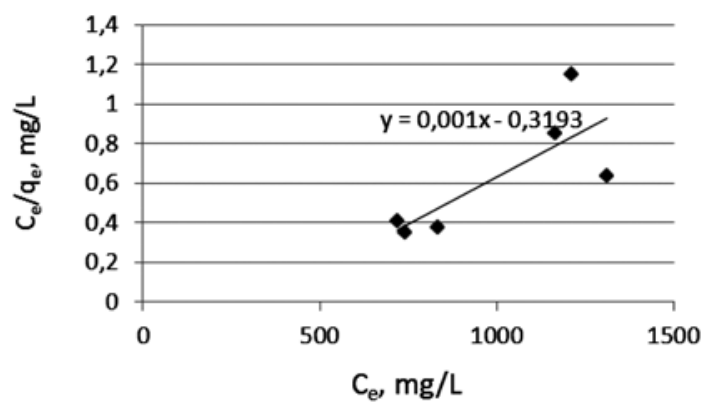

Fig. 3. Langmuir isotherm, when initial $\mathrm{NH}_{4}^{+}$concentrations in the sludge liquid were in range between $1420-1720 \mathrm{mg} / \mathrm{L}$ 
Once it was completed (the height of filter media $1.5 \mathrm{~m}$; the volume $2.3 \mathrm{~L}$ ) only $1 \mathrm{~L}$ of the sample could be filtered. TSS materials in the sludge liquor soon blocked the filter media. The efficiency of ammonium ions removal was in this case very high, i.e. $99.9 \%$; however, under laboratory conditions further filtering was impossible during the experiment due to a small surface area of the filter $(0.045 \mathrm{~m})$, where a layer of sediments appeared and the filter became hydraulically impermeable. Therefore, further research of the filter was carried out by reducing the height of the filter media to $0.5-1 \mathrm{~m}$ and choosing 1.6 to $2.5 \mathrm{~mm}$ sized zeolite particles. The results of ammonium ion concentration reduction in samples by filtering them through $1 \mathrm{~m}$ height filler are presented in Table 5. The primary $\mathrm{NH}_{4}^{+}$concentration in the sludge liquid was $1025 \mathrm{mg} / \mathrm{L}$.

Table 5. Ammonium ions removal, using column test (zeolite particles size $1.6-2.5 \mathrm{~mm}$ )

\begin{tabular}{cccc}
\hline $\begin{array}{c}\text { Filtered } \\
\text { volume, } \mathrm{L}\end{array}$ & $\begin{array}{c}\text { Filtration } \\
\text { run, min }\end{array}$ & $\begin{array}{c}\text { Removed } \mathrm{NH}_{4}^{+} \\
\text {concentration, mg/L }\end{array}$ & $\begin{array}{c}\text { Removal } \\
\text { efficiency, \% }\end{array}$ \\
\hline 1 & 5 & 937 & 91 \\
1.5 & 9 & 857 & 84 \\
2 & 14.5 & 795 & 78 \\
2.5 & 21.5 & 760 & 74 \\
3 & 30 & 752 & 73 \\
\hline
\end{tabular}

As can be seen from Table 5, the efficiency of ammonium ion removal from the samples decreased from 91 to $73 \%$ after half an hour. Liquor pollution had a considerable influence on that. Having noticed that the filter media can easily be blocked by suspended materials from the sludge liquid, the concentrations of pollutants were later reduced and the samples were left in a sedimentation unit for one day. The results of sedimentation experiment are reflected in Table 6.

Table 6. Experimental results of sedimentation process, initial $\mathrm{NH}_{4}^{+}$concentration in the sludge liquid was $1450 \mathrm{mg} / \mathrm{L}$, TSS $-1090 \mathrm{mg} / \mathrm{L}$

\begin{tabular}{|c|c|c|}
\hline $\begin{array}{l}\text { Sampling depth, } \\
\mathrm{m}\end{array}$ & $\begin{array}{l}{ }^{*} \mathrm{TSS} \\
\mathrm{mg} / \mathrm{L}\end{array}$ & $\begin{array}{c}{ }^{*} \mathrm{NH}_{4}{ }^{+} \text {concentration, } \\
\mathrm{mg} / \mathrm{L}\end{array}$ \\
\hline 0.50 & 920 & 1400 \\
\hline 1.00 & 870 & 1320 \\
\hline 1.50 & 1150 & 1540 \\
\hline
\end{tabular}

${ }^{\star}$ Note: Triple samples were analysed, from different sedimentation depth

Table 6 shows that the precipitation of sludge liquid was not efficient because the particles of over digested sludge were floating due to gas released bubbles. Suspended materials in the fugate are particularly small due to thermal sludge decomposition, which is carried out in the Lithuanian sludge treatment plant. When sludge is dewatered after digesting it by using conventional centrifuges - a considerable part of TSS is obtained into the fugate. A part of the disintegrated materials precipitated, due to which the highest concentrations of TSS were obtained at the bottom of the sedimentation unit, lower concentrations were observed on the surface and the minimum in the middle. As the sedimentation experiment was insufficient, new alternatives to reduce the concentration of suspended materials in the fugate more efficiently need to be found.

The volume of $13 \mathrm{~L}$ of sludge liquid from the sedimentation unit was filtered through the filler layer of $0.5 \mathrm{~m}$ height (0.8-1.6 $\mathrm{mm}$ zeolite fraction). The results are presented in Figure 4.

As can be seen from Figure 4, the efficiency of ammonium ion removal from sludge liquor decreases from 65 to $9 \%$ in 50 minutes of filtering. During the given period $13 \mathrm{~L}$ of sludge liquor were filtered. The speed of filtering was $\sim 10 \mathrm{~m} / \mathrm{h}$. In order to achieve better results of ammonium ion removal from the sludge liquor, the period in which the sludge liquid was stored in the filtering media need to be increased. The Figure 5 shows the results of ammonium ion removal from sludge liquor, where a sample of $2 \mathrm{~L}$ was filtered several times through the same filter media of $0.5 \mathrm{~m}$ height $(0.8-1.6 \mathrm{~mm}$ zeolite particles size) by using total retention time of $90 \mathrm{~min}$.

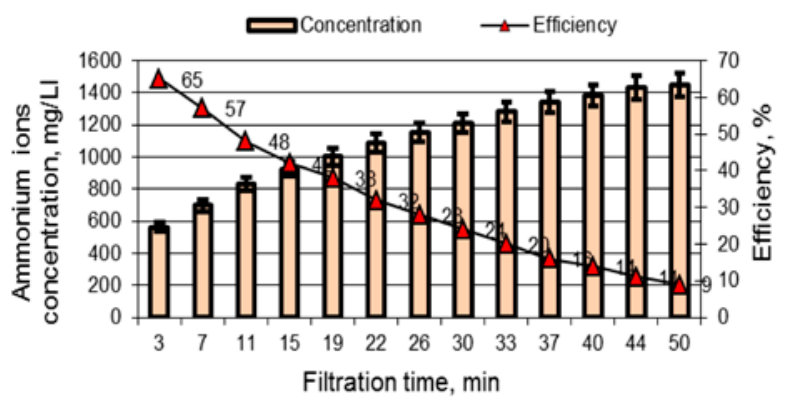

Fig. 4. Experimental results of ammonium ions removal efficiency (filtration run $50 \mathrm{~min}$ )

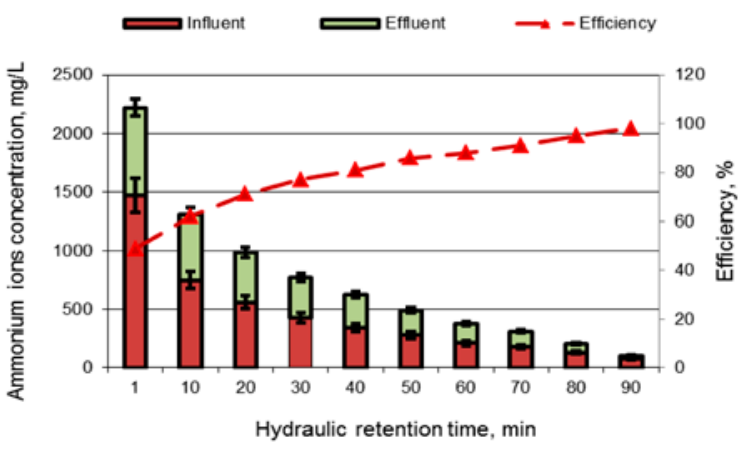

Fig. 5. Experimental results of ammonium ions removal efficiency (filtration run $90 \mathrm{~min}$ ) 
It can be seen that higher efficiency of ammonium ion removal is achieved by prolonging the period in which sludge liquid remained in the filter. Once the sample had remained in the filter media for 90 minutes, the efficiency reached $98 \%$, where in the beginning ( $1 \mathrm{~min}$ retention run) it only reached $49 \%$ (Fig. 5). In order to achieve maximum ammonium ions sorption a period of $1.5 \mathrm{~h}$ is needed while other parameters of the experiment were remained the same. During the lab-scale experiment it turned out that the filter media of $1 \mathrm{~L}$ volume $(0.5 \mathrm{~m}$ height, $0.8-1.6 \mathrm{~mm}$ fraction) would be sufficient to treat $2.5 \mathrm{~L}$ sludge liquid, where the primary concentration of ammonium ions were $1470 \mathrm{mg} / \mathrm{L}$.

It was observed that doing filtration of fugate, the zeolite do not aggregates into monolith mass, and nor layering. When using zeolite for fugate treatment, after the ammonium ions sorption, the zeolite can be reutilized. As it is pointed out in scientific literature (Vesela et al. 2003; Montemurro et al. 2007; Rehaková et al. 2004; BelerBaykal, Allar 2008; Lija et al. 2012), zeolite saturated with ammonium ions could be successfully used in agriculture as it is a nitrogen fertilizer.

Results of the elements X-Ray Fluorescence analysis in samples (average values) are presented in Table 7.

As can be seen from Table 7, the almost all average values of heavy metals ( $\mathrm{As}, \mathrm{Pb}, \mathrm{Zn}, \mathrm{Cu}$ ) in samples of $\mathrm{fu}$ gate are higher or in samples of natural zeolite. Only $\mathrm{Cr}$ (10 times) and $\mathrm{Hg}$ (1,5 times) in zeolite exceeds the values of fugate. Used zeolite (after sorption) is not contaminated with $\mathrm{Rb}, \mathrm{Se}, \mathrm{Fe} . \mathrm{Cd}, \mathrm{Ag}, \mathrm{Pb}, \mathrm{Ni}, \mathrm{Co}, \mathrm{Cr}, \mathrm{V}, \mathrm{Sn}, \mathrm{Pd}, \mathrm{Au}, \mathrm{W}$ concentrations are below the level of detection. Results of the obtained elements X-Ray Fluorescence analysis presented in Table 7, can be compared along with maximum allowable concentrations for the wastewater sludge of I-III category (LAND 20-2005). Almost all average values of heavy metals in zeolite fugate samples do not exceed the concentrations that are determined for the I sludge category. The amounts of $\mathrm{Cd}$ and $\mathrm{Ni}$ were below detection limits and $\mathrm{Hg}$ in all samples exceeds the requirements for I sludge category. Fugate and zeolite samples were attributed to the II category sludge which means that sediments are slightly polluted with heavy metals and can be used with restrictions that are specified in Lithuanian environmental normative document (LAND 20-2005).

One of the most common methods for assessing quantifying metal enrichment is to compare identified concentrations with a background level or with a concentration posing serious environmental risks (e. g. maximum concentration defined in legal environmental regulations and guidelines). Amount of $\mathrm{Ca}, \mathrm{K}, \mathrm{S}$ in zeolite samples increased significantly after sorption process. The following elements are known to be essential for plant growth. Calcium, potassium and sulphur normally derived from the soil in the form of inorganic salts. Potassium with nitrate and phosphates in high amount are required to all plants and microorganisms nutrition. Saturated zeolite can be used as excellent fertilizer because the plants can assimilate valuable materials step by step, and those materials can be assimilated from the zeolite only by plants roots (Ahmed et al. 2010). Additional and well balanced material transportation to prior- roots zone is going on. Therefore we cannot over-fertilise the soil. Plants roots start dissolving reactions because of absorption, and needed nutrients are accessible. Thereafter the zeolite is saturated with excess materials again (Vesela et al. 2003). Nitrogen compounds are not washed out to the ground water and the zeolite particles improve the structure of soil (Montemurro et al. 2007). This material fulfils soil with mineral compounds. However, according to (Rehaková et al. 2004) such zeolite is not harmful to nature as the sludge of wastewater in the wastewater treatment unit is treated in the thermal hydrolysis phase, where pathogenic bacteria and helminthic eggs are deactivated. Therefore zeolite could be used to

Table 7. Composition of elements in substances

\begin{tabular}{|c|c|c|c|}
\hline \multirow[t]{2}{*}{ Element } & Fugate & $\begin{array}{c}\text { Natural zeolite } \\
\text { before sorption }\end{array}$ & $\begin{array}{c}\text { Zeolite after } \\
\text { sorption }\end{array}$ \\
\hline & \multicolumn{3}{|c|}{ ppm } \\
\hline As & 5.15 & $<\mathrm{LOD}^{*}$ & 4.55 \\
\hline $\mathrm{Hg}$ & 2.45 & 3.62 & 3.72 \\
\hline $\mathrm{Cd}$ & $<\mathrm{LOD}$ & $<\mathrm{LOD}$ & $<\mathrm{LOD}$ \\
\hline $\mathrm{Ba}$ & $<\mathrm{LOD}$ & $<\mathrm{LOD}$ & $<\mathrm{LOD}$ \\
\hline $\mathrm{Sb}$ & $<\mathrm{LOD}$ & $<\mathrm{LOD}$ & $<\mathrm{LOD}$ \\
\hline $\mathrm{Ag}$ & $<\mathrm{LOD}$ & $<\mathrm{LOD}$ & $<\mathrm{LOD}$ \\
\hline $\mathrm{Zr}$ & 10.88 & 96.14 & 101.4 \\
\hline $\mathrm{Sr}$ & 135.26 & 325.32 & 346.45 \\
\hline $\mathrm{Rb}$ & 16.53 & 101.08 & 92.36 \\
\hline $\mathrm{Pb}$ & 8.19 & $<\mathrm{LOD}$ & $<\mathrm{LOD}$ \\
\hline $\mathrm{Se}$ & 2.42 & 3.03 & 2.65 \\
\hline $\mathrm{Zn}$ & 934.52 & 31.44 & 114.62 \\
\hline $\mathrm{Cu}$ & 164.18 & $<\mathrm{LOD}$ & 16.24 \\
\hline $\mathrm{Ni}$ & $<\mathrm{LOD}$ & $<\mathrm{LOD}$ & $<\mathrm{LOD}$ \\
\hline Co & $<\mathrm{LOD}$ & 48.64 & $<\mathrm{LOD}$ \\
\hline $\mathrm{Fe}$ & 5149.52 & 7368.63 & 6268.46 \\
\hline $\mathrm{Mn}$ & 96.06 & 241.72 & 254.27 \\
\hline $\mathrm{Cr}$ & $<$ LOD & 10.83 & $<\mathrm{LOD}$ \\
\hline $\mathrm{V}$ & $<\mathrm{LOD}$ & $<\mathrm{LOD}$ & $<\mathrm{LOD}$ \\
\hline $\mathrm{Ti}$ & 2198.14 & 998.07 & 1018.78 \\
\hline $\mathrm{Sc}$ & 495.52 & 62.82 & 107.54 \\
\hline $\mathrm{Ca}$ & 117548.32 & 15277.6 & 38713.44 \\
\hline K & 40505.78 & 21749.2 & 22560.45 \\
\hline$S$ & 12055.89 & $<\mathrm{LOD}$ & 674.48 \\
\hline Sn & $<\mathrm{LOD}$ & $<\mathrm{LOD}$ & $<\mathrm{LOD}$ \\
\hline $\mathrm{Pd}$ & $<$ LOD & $<\mathrm{LOD}$ & $<\mathrm{LOD}$ \\
\hline $\mathrm{Au}$ & $<\mathrm{LOD}$ & $<\mathrm{LOD}$ & $<\mathrm{LOD}$ \\
\hline $\mathrm{W}$ & $<$ LOD & $<$ LOD & $<$ LOD \\
\hline
\end{tabular}


reduce the use of $\mathrm{N}, \mathrm{P}$ and $\mathrm{K}$ fertilizers on acid soils (Lija et al. 2012). The mostly useful fraction to the plants roots is 2-5 mm (Rehaková et al. 2004).

In the present study the smallest zeolite fraction $(0.8-$ $16 \mathrm{~mm}$ ) proved to be the most efficient to reduce ammonium ions concentration in the sludge liquor. When used in production, the hydraulic permeability of filter can be decreased, as there is a number of TSS in sludge liquor. During lab-scale experiments, the height of filter media should not exceed $50 \mathrm{~cm}$; however, the same or several filters gradually following one another can be used several times. Having assessed high $\mathrm{NH}_{4}{ }^{+}-\mathrm{N}$ concentrations and a poor precipitation of suspended materials (when the fugate is kept in the sedimentation unit for one day), it can be presumed that sludge under digestion was not fully stabilized in the course of the experiment. The fact that ammonium ions are still generated in sludge liquid after one day of storage shows further decomposition of organic materials.

This fact only proves the need for the reduction of ammonium ions concentration in the fugate before it is returned to the wastewater treatment stage. The present studies are valuable as the concentration of ammonium ions in the fugate can be reduced considerably by means of simple filtration through the zeolite filter media with no chemical reagent employed.

\section{Conclusions}

The results showed a high concentration of ammonium ions $(1025-1750 \mathrm{mg} / \mathrm{L})$ in the samples of digested sludge liquor collected from the Lithuanian wastewater treatment plant. These results confirm the hypothesis that the dewatering of sludge in centrifuges leads to higher ammonium concentrations in fugate, as predicted in scientific literature. To reduce the $\mathrm{NH}_{4}^{+}-\mathrm{N}$ concentration of fugate the samples were mixed with zeolite fractions and an efficiency of $90 \%$ was reached. In the present study $1 \mathrm{~g}$ of zeolite can remove up to $2.2 \mathrm{mg}$ of ammonium ions only. This is due to high pollution of the sludge liquid (concentration of ammonium ions - up to $1750 \mathrm{mg} / \mathrm{L}$ ) and high TSS concentrations in the fugate (up to $1220 \mathrm{mg} / \mathrm{L}$ ).

The $\mathrm{NH}_{4}^{+}-\mathrm{N}$ concentrations in digested sludge liquor can be reduced up to $\sim 98 \%$ when the fugate is filtered through the zeolite filler of $0.5 \mathrm{~m}$ height $(0.8-1.6 \mathrm{~mm}$ particles size zeolite) several times.

It was observed that doing filtration of fugate, the zeolite do not aggregates into monolith mass, and nor layering. This sorbent is interfering with the water not only as filtration material, but also like adsorbent and as ion exchange carrying out material. Zeolite saturated with ammonium ions possibly can be used in agriculture as nitrogenous fertilizers. To gain deeper knowledge of this, research can be done to investigate cultivation in practice.
Obtained fertilizer grade of zeolite saturated with fugate can also be produced from the high ammonium nitrogen concentration side-streams separated from wastewater flow from sludge digestion processes by sorption on zeolite filter media.

\section{Acknowledgements}

We would like to thank the administration of JSC "Vilniaus vandenys" (Vilnius, Lithuania) and colleagues for the possibility to carry out the experiments with fugate that is generated at wastewater treatment plant.

\section{References}

Ahmed, O. H.; Braine, C. H; Muhamad, A. M. 2010. Minimizing of ammonia loss through mixing with zeolite and acid sulphate soil, International Journal of Physical Sciences 5(14): 2198-2202.

Bao-Shan Xing; Qiong Guo; Guang-Feng Yang; Zheng-Zhe Zhang; Peng Li; Li-Xin Guo; Ren-Cun Jin. 2015. The properties of anaerobic ammonium oxidation (anammox) granules: Roles of ambient temperature, salinity and calcium, Separation and Purification Technology 147: 311-318. http://dx.doi.org/10.1016/j.seppur.2015.04.035

Beler-Baykal, B.; Allar, A. D. 2008. Upgrading fertilizer production wastewater effluent quality for ammonium discharges through ion exchange with clinoptilolite, Environmental Technology 29(6): 665-672. http://dx.doi.org/10.1080/09593330801987004

Calli, B.; Mertoglu, B.; Inanc, B.; Yenigun, O. 2005. Effects of high free ammonia concentrations on the performances of anaerobic bioreactors, Process Biochemistry 40(3-4): 12851292. http://dx.doi.org/10.1016/j.procbio.2004.05.008

Cheng, G. V., et al. 2011. A study on the ammonia removal mechanisms for the A/O biological nitrogen removal process with the enchancement of the zeolite, Advanced Materials Research 322: 52-56. http://dx.doi.org/10.4028/www.scientific.net/AMR.322.52

Constantine, T. 2006. North American experience with centrate treatment technologies for ammonia and nitrogen removal, Proceedings of the Water Environment Federation 2006: 52715281. http://dx.doi.org/10.2175/193864706783763291

Du, Q.; Liu, S.; Cao, Z.; Wang, Y. 2005. Ammonia removal from aqueous solution using natural Chinese clinoptilolite, Separation and Purification Technology 44: 229-234. http://dx.doi.org/10.1016/j.seppur.2004.04.011

Farkas, A.; Rozic, M.; Barbaric-Mikocevic, Z. 2005. Ammonium exchange in leakage waters of waste dumps using natural zeolite from the Krapina region, Croatia, Journal of Hazardous Materials 117: 25-33. http://dx.doi.org/10.1016/j.jhazmat.2004.05.035

Jafarpour, M.; Foolad, A.; Mansouri, M.; Nikbakhsh, Z.; Saeedizade, H. 2010. Ammonia removal from nitrogenous industrial waste water using Iranan natural zeolite of Clinoptilolite type, Engineering and Technology 70: 939-945.

Gustavsson, D. 2010. Biological sludge liquor treatment at municipal wastewater treatment plants - a review, Journal of Water Management and Research 66: 179-192. 
Hedstrom, A. 2001. Ion exchange of ammonium in zeolites: a literature review, Journal of Environmental Engineering 127(8): 673-681. http://dx.doi.org/10.1061/(ASCE)07339372(2001)127:8(673)

Huang, H.; Xiao, B.; Yan, L. 2010. Ammonium removal from aqueous solutions by using natural Chinese (Chende) zeolite as adsorbent, Journal of Hazardous Materials 175: 247-252. http://dx.doi.org/10.1016/j.jhazmat.2009.09.156

Inglezakis, V. J. 2005. The concept of "capacity" in zeolite ion-exchange systems, Journal of Colloid and Interface Science 281: 68-79. http://dx.doi.org/10.1016/j.jcis.2004.08.082

Ivanova, E.; Karsheva, M.; Koumanova, B. 2010. Adsorption of ammonium ions onto natural zeolite, Journal of the University of Chemical Technology and Metallurgy 45(3): 295-302.

Karapinar, N. 2009. Application of natural zeolite for phosphorus and ammonium removal from aqueous solutions, Journal of Hazardous Materials 170(2-3): 1186-1191. http://dx.doi.org/10.1016/j.jhazmat.2009.05.094

Kurama, H.; Poetzschke, J.; Haseneder R. 2002. The application of membrane filtration for the removal of ammonium ions from potable water, Water Research 36(12): 2905-2909. http://dx.doi.org/10.1016/S0043-1354(01)00531-0

LAND 20-2005. Water quality. Use of sewage sludge as fertilizer requirements. Lithuanian Ministry of Environment, 2015, D1-867.

LAND 46-2007. Water quality. Determination of suspended solids. Filtration through glass fiber filters. Lithuanian Ministry of Environment, 2007, D1-412.

Lebedynets, M.; Sprinskyy, M.; Sakhnyuk, I.; Zbytniewsky, I.; Golembiewsky, R.; Buszewsky, B. 2004. Adsorption of ammonium ions onto a natural zeolite: Transcarpathian clinoptilolite, Adsorption Science \& Technology 22(9): 731-741. http://dx.doi.org/10.1260/0263617043026541

Lija, W. B. M.; Ahmed, O. H.; Kasim, S. 2012. Reducing ammonia volatilization from compound fertilizers amended with zeolite, African Journal of Biotechnology 11: 13903-13906.

Mažeikiene, A.; Valentukevičiene, M.; Rimeika, M.; Matuzevičius, A. B.; Dauknys, R. 2008. Removal of nitrates and ammonium ions from water using natural sorbent zeolite (clinoptilolite), Journal of Environmental Engineering and Landscape Management 16(1): 38-44.

http://dx.doi.org/10.3846/1648-6897.2008.16.38-44

Miladinovic, N.; Weatherley, L. R. 2008. Intensification of ammonia removal in a combined ion-exchange and nitrification column, Chemical Engineering Journal 135(1-2): 15-24. http://dx.doi.org/10.1016/j.cej.2007.02.030

Monballiu, A.; Desmidt, E.; Ghyselbrecht, K.; De Clippeleir, H.; Van Hulle, S. V. H.; Verstraete, W.; Meesschaert, B. 2013. Enrichment of anaerobic ammonium oxidizing (Anammox) bacteria from OLAND and conventional sludge: features and limitations, Separation and Purification Technology 104: 130137. http://dx.doi.org/10.1016/j.seppur.2012.10.046

Montemurro, F.; Maiorana, M.; Lacertosa, G. 2007. Plant and soil nitrogen indicators and performance of tomato grown at different nitrogen fertilization levels, Journal of Food, Agriculture \& Environment 5(2): 143-148.

Rahmani, R., et al. 2004. Investigation of ammonia removal from polluted waters by Clinoptilolite zeolite, International Journal of Environmental Science \& Technology 1(2): 125-133. http://dx.doi.org/10.1007/BF03325825
Rehaková, M.; Cuvanová, S.; Dzivak, M.; Rimarb, J.; Gavalovac, Z. 2004. Agricultural and agrochemical uses of the clinoptilolite type, Current Opinion in Solid State and Material Science 8(6): 397-404.

http://dx.doi.org/10.1016/j.cossms.2005.04.004

Rezaei, M.; Mehrnia, M. R.; Sarrafzadeh, M. H. 2014. Effect of clinoptilolite addition on nutrient removal in a membrane bioreactor, Desalination and Water Treatment 54(11): 29202927. http://dx.doi.org/10.1080/19443994.2014.913203

Rožič, M.; Cerjan-Stefanovic, Š.; Kurajica, S.; Vančina, V.; Hodžic, E. 2000. Ammoniacal nitrogen removal from water by treatment with clays and zeolites, Water Research 34(14): 3675-3681.

http://dx.doi.org/10.1016/S0043-1354(00)00113-5

Sakalauskas, A.; Valentukevičienè, M. 2003. Investigation into the influence of natural powered zeolite on drinking water treatment at Druskininkai waterworks III, Journal of Environmental Engineering and Landscape Management 11(4): 69-178.

Saltah, K., et al. 2007. Removal of ammonium ion from aqueous solution by natural Turkish (Yildizeli) zeolite for environmental quality, Journal of Hazardous Materials 141: 258-263. http://dx.doi.org/10.1016/j.jhazmat.2006.06.124

Sileg, M.; Folgar, L.; Kukucka, M. 2010. The groundwater ammonium sorption onto Croatian and Serbian clinoptilolite, Journal of Hazardous Materials 178: 572-577. http://dx.doi.org/10.1016/j.jhazmat.2010.01.123

Sprinsky, M.; Lebedynets, M.; Terzyk, A. P.; Kowalczyk, P.; Namiesnik, J.; Buszewsky, B. 2005. Ammonium sorption from aqueous solutions by the natural zeolite Transcarpathian Clinoptilolite studied under dynamic conditions, Journal of Colloid and Interface Science 284: 408-415. http://dx.doi.org/10.1016/j.jcis.2004.10.058

Tada, Ch., et al. 2005. Effect of natural zeolite on methane production for anaerobic digestion of ammonium rich organic sludge, Bioresource Technology 96: 459-464. http://dx.doi.org/10.1016/j.biortech.2004.05.025

Thornton, A.; Pearce, P.; Parsons, S. A. 2007. Ammonium removal from digested sludge liquors using ion exchange, Water Research 41: 433-439. http://dx.doi.org/10.1016/j.watres.2006.10.021

Vabolienè, G.; Matuzevičius, A. B.; Valentukevičienė, M. 2007. Effect of nitrogen on phosphate reduction in biological phosphorus removal from wastewater, Ekologija 53 (1): 80-88.

Valentukevičienė, M.; Jankauskas, J. 2004. The invention of using natural adsorbents for the treatment of natural water. Lithuanian Patent Nr. 5104 B. CO2F 1/28.

Valentukevičienè, M.; Rimeika, M. 2007. Development of a fluidized batch process using natural powdered zeolite (clinoptilolite), Polish Journal of Environmental Studies 16(2): 283-288.

Vassileva, P.; Voikova, D. 2009. Investigation on natural and pretreated Bulgaran clinoptilolite for ammonium ions removal from aqueous solutions, Journal of Hazardous Materials 170(2-3): 948-957. http://dx.doi.org/10.1016/j.jhazmat.2009.05.062

Vesela, M.; Drdak, M.; Sandara, S. 2003. Relation between free amino acids and the biogenic amines contents in green tomatoes inoculated with Lactobacillus plantarum, Czech Journal of Food Science 21: 51-58. 
Wang, F.; Ding, Y.; Ge, L.; Ren, H.; Ding, L. 2010. Effect of highstrength ammonia nitrogen acclimation on sludge activity in sequencing batch reactor, Journal of Environmental Sciences 22(11): $1683-1688$.

http://dx.doi.org/10.1016/S1001-0742(09)60306-5
Zekker, I.; Rikmann, E.; Tenno, T.; Kroon, K.; Seiman, A.; Loorits, L.; Fritze, H.; Tuomivirta, T.; Vabamäe, P.; Raudkivi, M.; Mandel, A.; Taavo, T. 2014. Start-up of low-temperature anammox in UASB from mesophilic yeast factory anaerobic tank inoculum, Environmental Technology 35(24): 1-12.

Aušra MAŽEIKIENĖ. Dr., Assoc. Prof., Dept of Water Management, Vilnius Gediminas Technical University (VGTU), Lithuania. Doctor of Science (environmental engineering), VGTU, 2005. Author of more than 25 research papers. Research interests: water treatment, ecotechnologies for water management.

Marina VALENTUKEVIČIENĖ. Dr., Assoc. Prof., Dept of Water Management, Vilnius Gediminas Technical University (VGTU), Lithuania. Doctor of Science (environmental engineering), VGTU, 2003. Author of more than 30 research papers. Research interests: water treatment, ecotechnologies for water management. 